Pure Sciences

Poster

Abstract ID: 149

\title{
The effect of particle size, methods and time of extraction on the natural antioxidant content and radical scavenging activity of Phyllanthus niruri
}

Noraslinda Muhamad Bunnori | Deny Susanti Darnis | Muhammad Najib Yusof | Khairul Bariyyah Abd. Halim

Kulliyyah of Science, International Islamic University Malaysia

Introduction: Phyllanthus niruri has a high antioxidant capacity due to high phenolic and flavonoid content. This study is to determine and evaluate the effect of particle size, methods and time of extraction on its antioxidant activities. Methods: $P$. niruri was dried overnight in drier at $40^{\circ} \mathrm{C}$ and grounded to different particle sizes. The extraction methods by using a rotary evaporator were soxhlet and maceration. Three types of biochemical assays were conducted: total phenolic content (TPC), total flavonoids content (TFC) and 1,1-Diphenyl-2 picrylhydrazyl (DPPH) radical scavenging activity assay. Result: The best TPC and DPPH value are recorded for the sample of less than $0.7 \mathrm{~mm}$, treated by a soxhlet extraction method at 8 hours extraction time with TPC valued at $4.95 \pm 0.803 \mathrm{mg}$ $\mathrm{GAE} / \mathrm{g}$ of dried extract and $\mathrm{IC}_{50}$ value of $0.403 \pm 0.03790 \mathrm{mg} / \mathrm{mL}$ respectively. The highest TFC amount is recorded for the sample treated at less than $0.7 \mathrm{~mm}$ particle size, by the maceration method of extraction and at 8 hours extraction time with the total flavonoid content of $56.43 \pm 0.594 \mathrm{mg} \mathrm{QE} / \mathrm{g}$ of dried extract. Conclusions: It can be concluded that there are a synergistic effect between TPC and TFC on the quality of the anti-radical property of the sample affecting DPPH activity within the sample.

KEYWORDS: Phyllanthus niruri, antioxidant, total phenolic content, total flavonoids content, 1,1Diphenyl-2 picrylhydrazyl 